\section{VERBOS DE PIEDRA} C Cruz convierte un versículo bíblico en latín en un verso castellano. Conocemos bien el evangelio: el verbo lo hace todo. Pero en la lengua castellana del poeta, el Verbo moraba, al principio.

Para la artista peruana Gihan Tubbeh no se trataría de un Verbo sino de muchos, y en piedra, explícitamente. No podría uno imaginar morada más sólida y fija. Pero su más reciente cuerpo de obra apunta a otra cosa: ella elige mostrarnos cómo lo sólido se funde en el aire gélido. El hielo se hace agua. Y cómo sin embargo, se produce también lo inverso: un líquido ígneo, la lava, se enfría y se vuelve el corazón de planeta en Islandia es fugaz, pero cuestiona las convenciones establecidas, para crear algo que ya no es un paisaje, sino un conjunto de variables de temperatura y cambios de estado de la materia. De luz-calor y de sombra-frio.

La piedra también se hace polvo. Y vuela en el aire seco de Samaca, en el desierto de lca. Es un suelo que antes fue fondo marino, que acumuló capa tras capa de lodo en múltiples sedimentos que hoy están al descubierto. Erosionados por el viento y por el agua que puede bajar en torrente de las alturas, estos sedimentos están en su lugar: moradas en las que Gihan Tubbeh se detiene y reposa el espíritu en un instante fugaz, para recoger una huella.

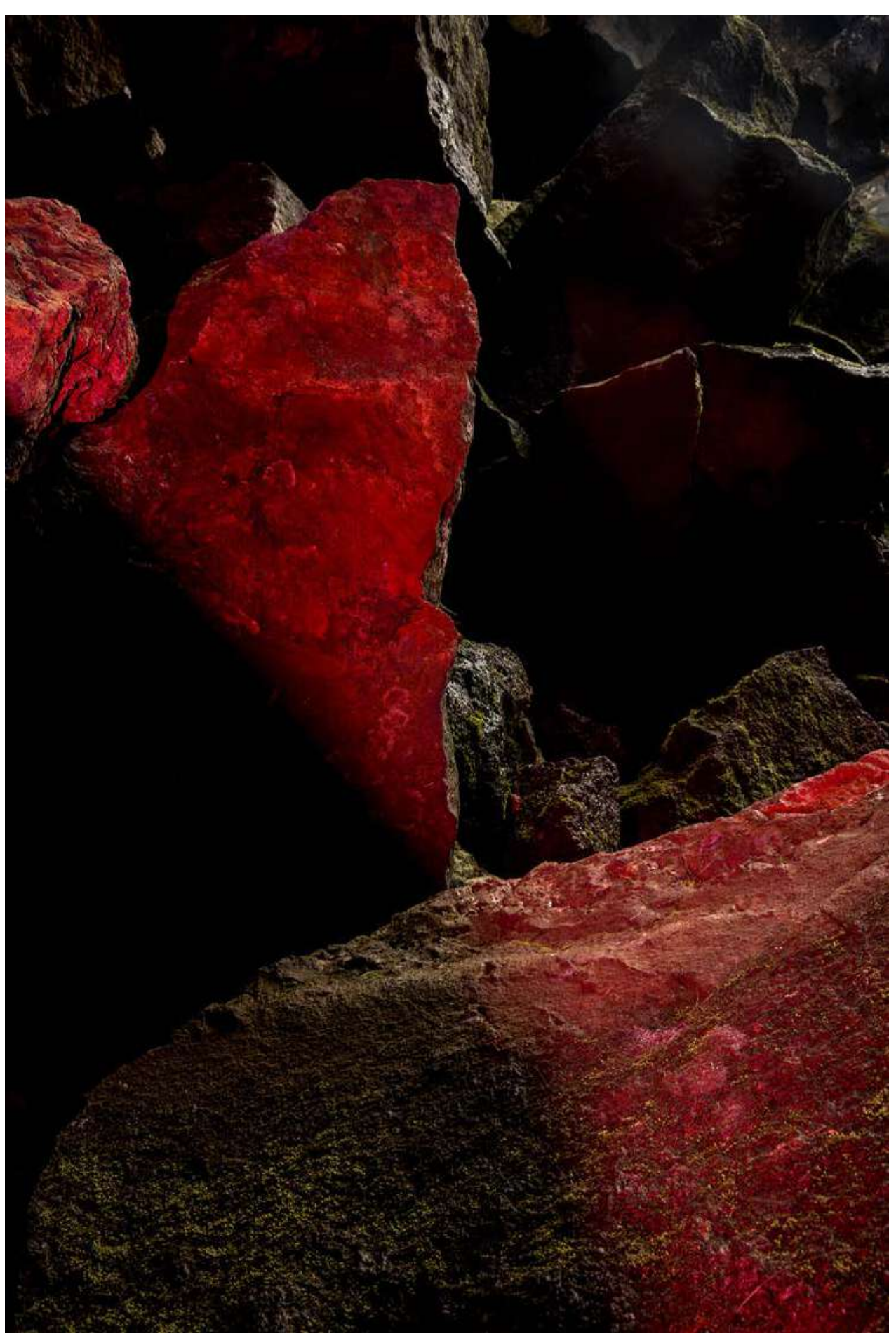

Escritura de Lava 
Entonces, en estas imágenes son otros los verbos y no moran en la eternidad de la piedra -el lugar común que nos han inculcado con el arte escultórico de la antigüedad clásica, o tributario de éstesino en las formas de la materia en flujo, que provienen del transcurso del tiempo geológico, o simplemente responden a cambios climatológicos. La dimensión temporal es a veces impredecible y otras veces inabarcable. En los verbos de Tubbeh habita la mutabilidad de la materia bajo los procesos que la generan o transforman.

La piedra de sus verbos es densa, traslúcida, elástica y proteica rugosa y delicuescente, casada con el hielo, el fuego y atmósferas magnéticas. El horizonte humano no se despega de ella, y aunque ésta desaparezca del imaginario de la diaria rutina urbana, es uno de los anclajes fecundos de la imaginación y de las formas arquetípicas que penan en ella.

Es de la imaginación preñada por este misterio, que han nacido los mitos antiguos que encendieron e iluminaron a las mentes. De la oralidad de las narrativas iniciales, a la escritura en todas sus formas, los mitos mantienen vivas las múltiples lenguas imaginarias de la materia. Su luz quedó en la cerámica y en la piedra, alentando la sed de esclarecer los destinos.

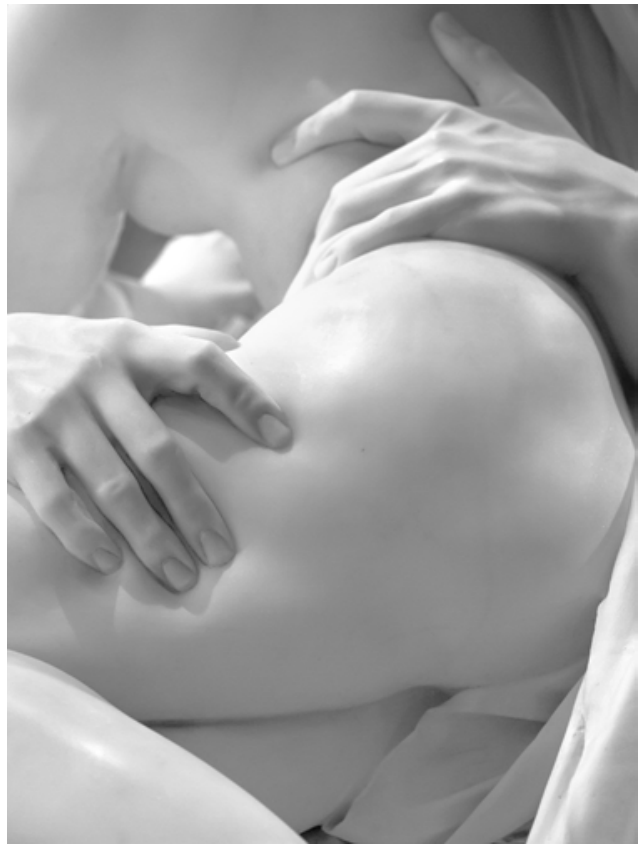

Perséfone

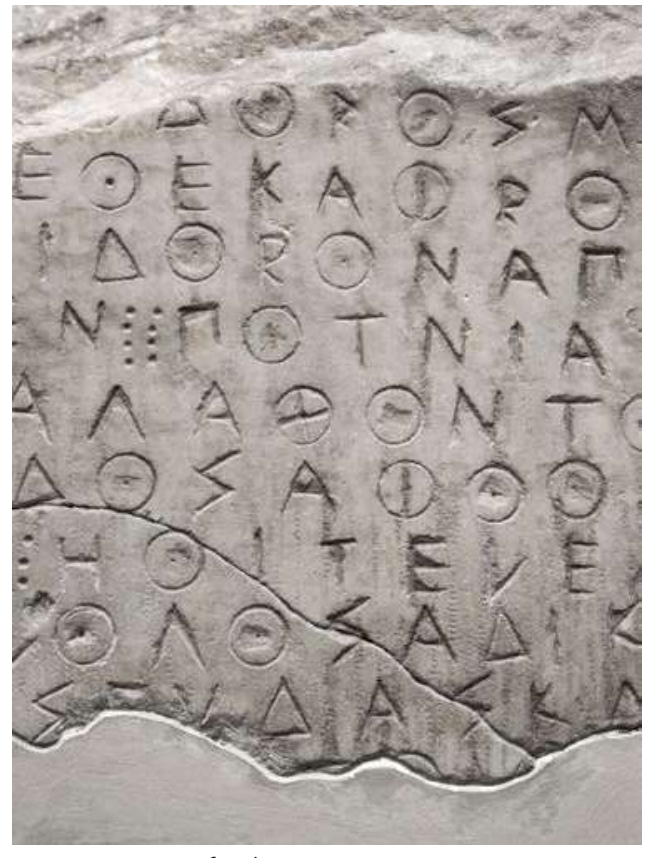

Escritura para afrodita

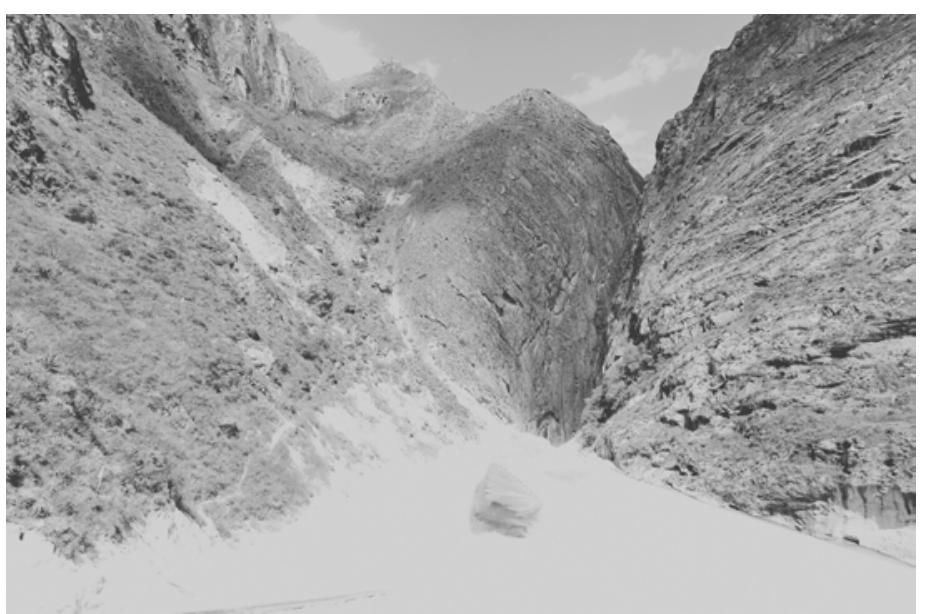

Quebrada blanca

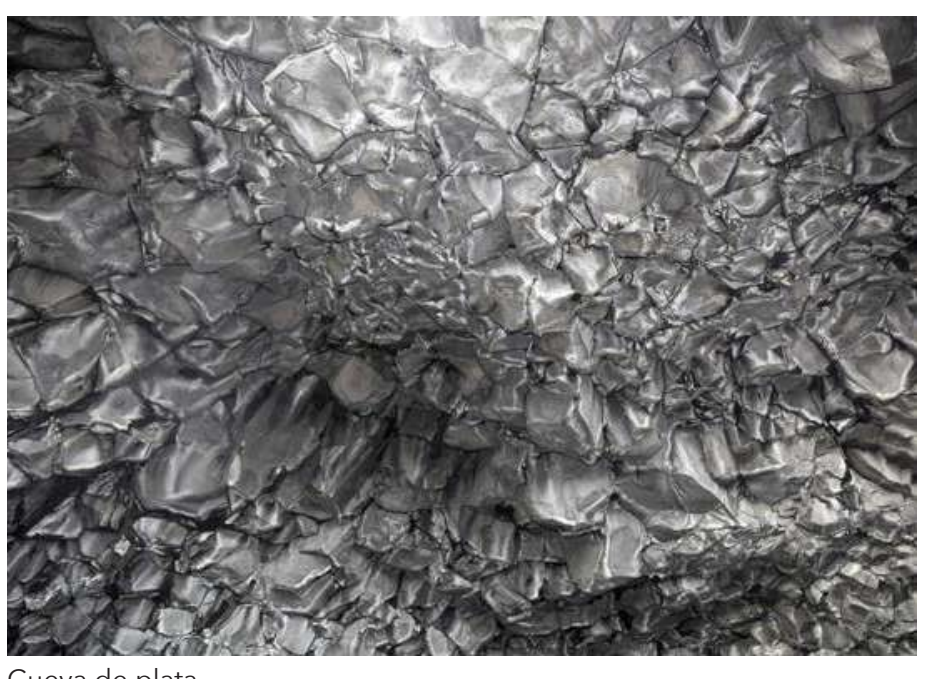

Cueva de plata

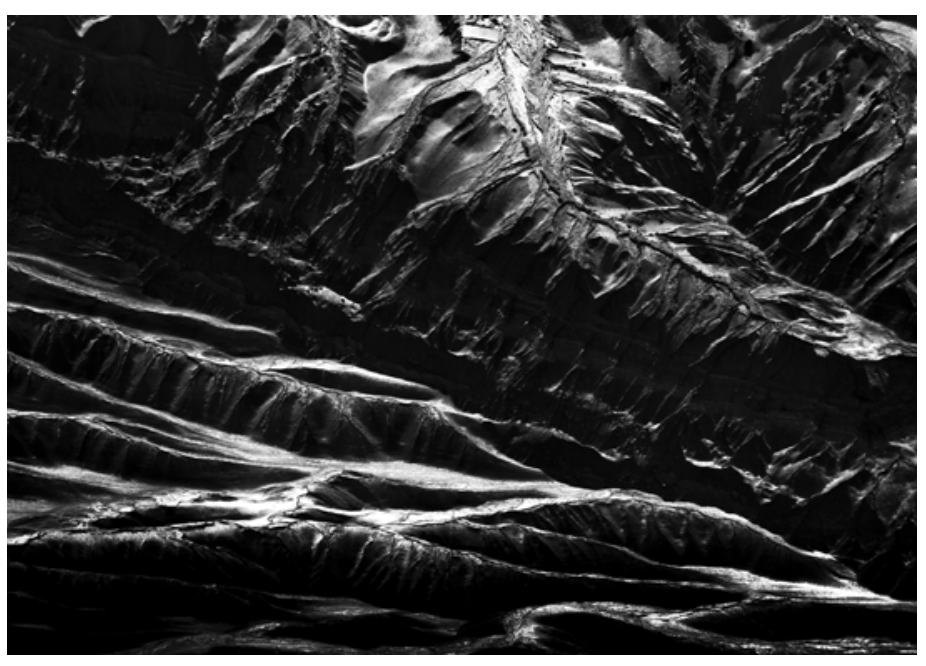

Cordillera negra 


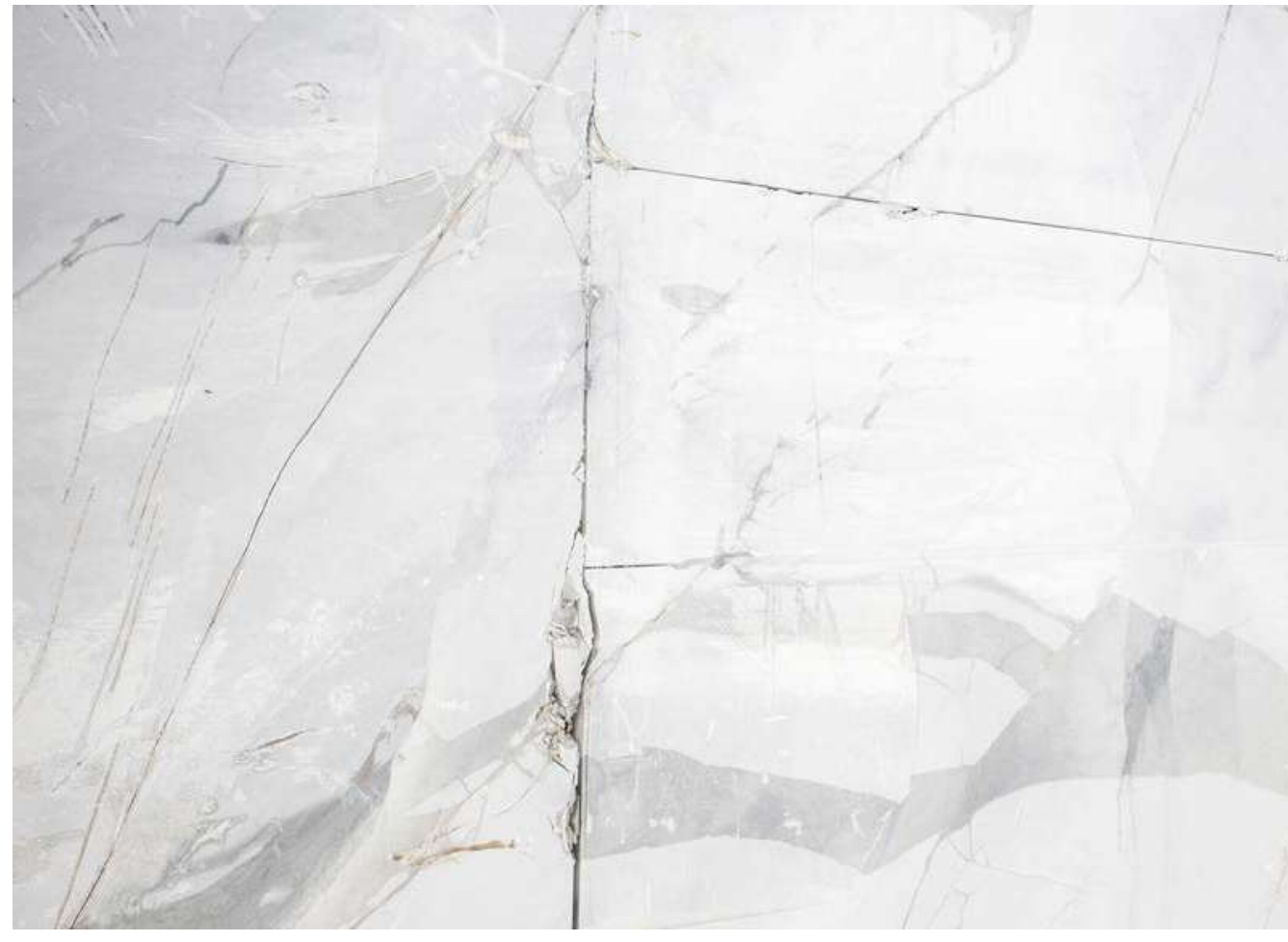

Carrara

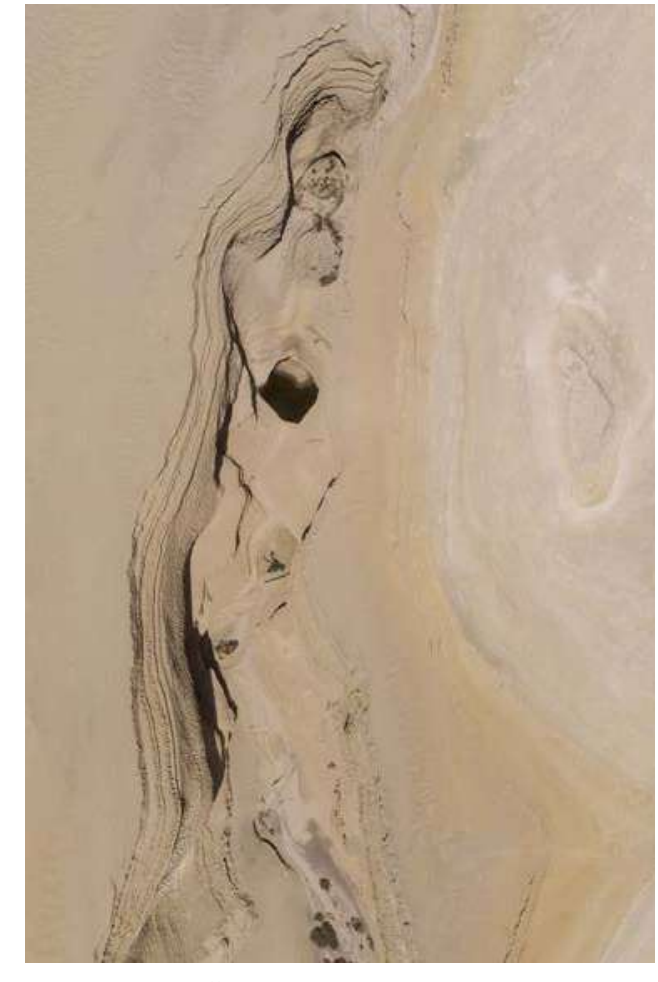

Huayco amarrillo

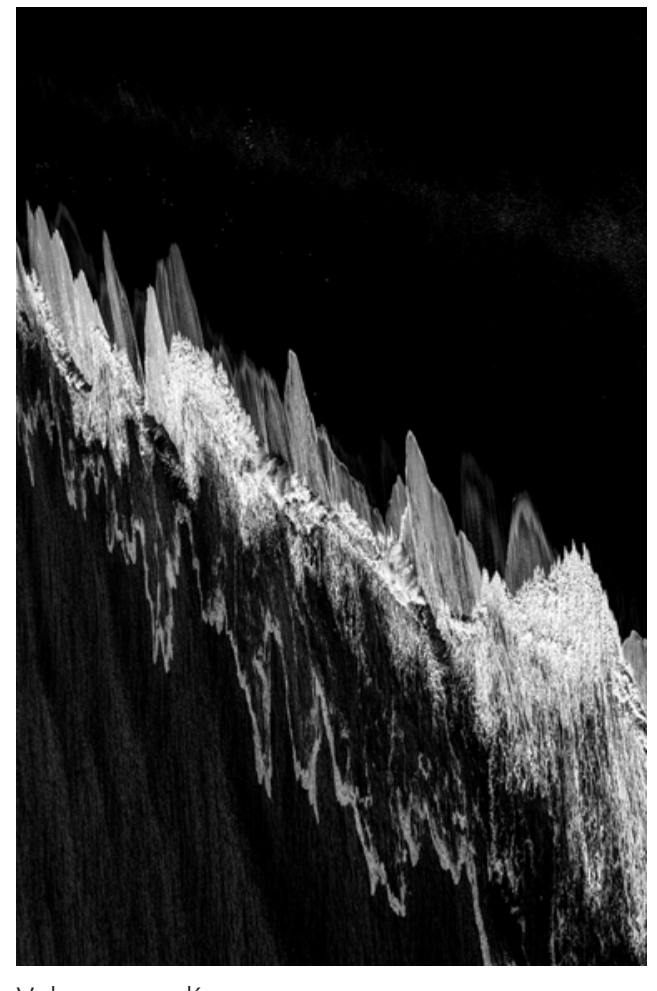

Volcanes cardíacos

Verbos de Piedra se asemeja a una arqueología poética, que no aspira a alcanzar el sello de lo concluyente. Busca señales y ritmos ocultos en el mundo visible. En estas imágenes, así como en la poesía, la alquimia del arte captura ecos de algo inconmensurablemente más grande que nuestras huellas en el paisaje. El rumor de un

lenguaje codificado indescifrable. Una escritura secreta que a veces permite que surjan armonías que se eclipsan en el misterio. •

Jorge Villacorta Chávez 


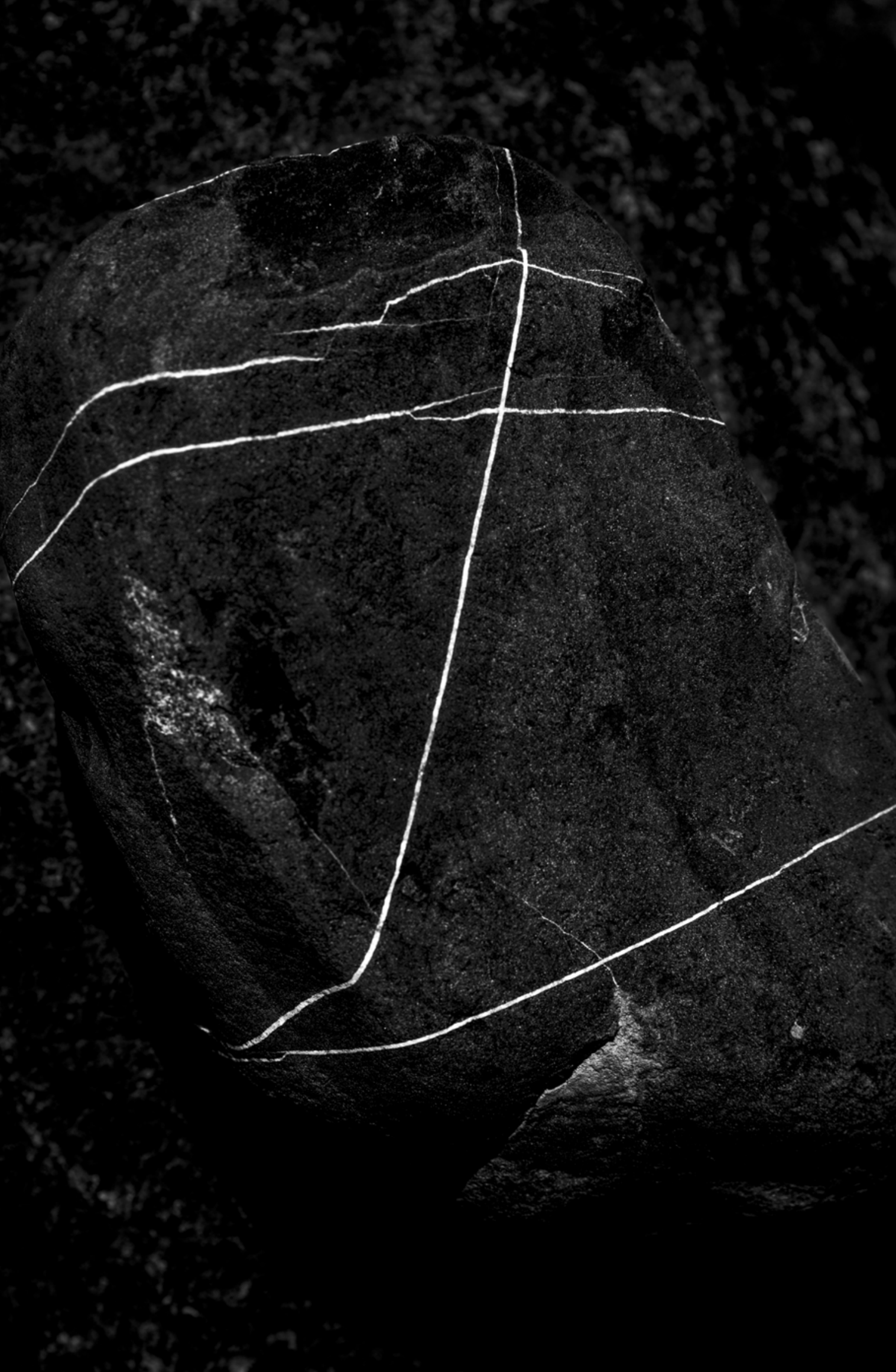

$3 y^{2} \cdot x^{2} y$ 


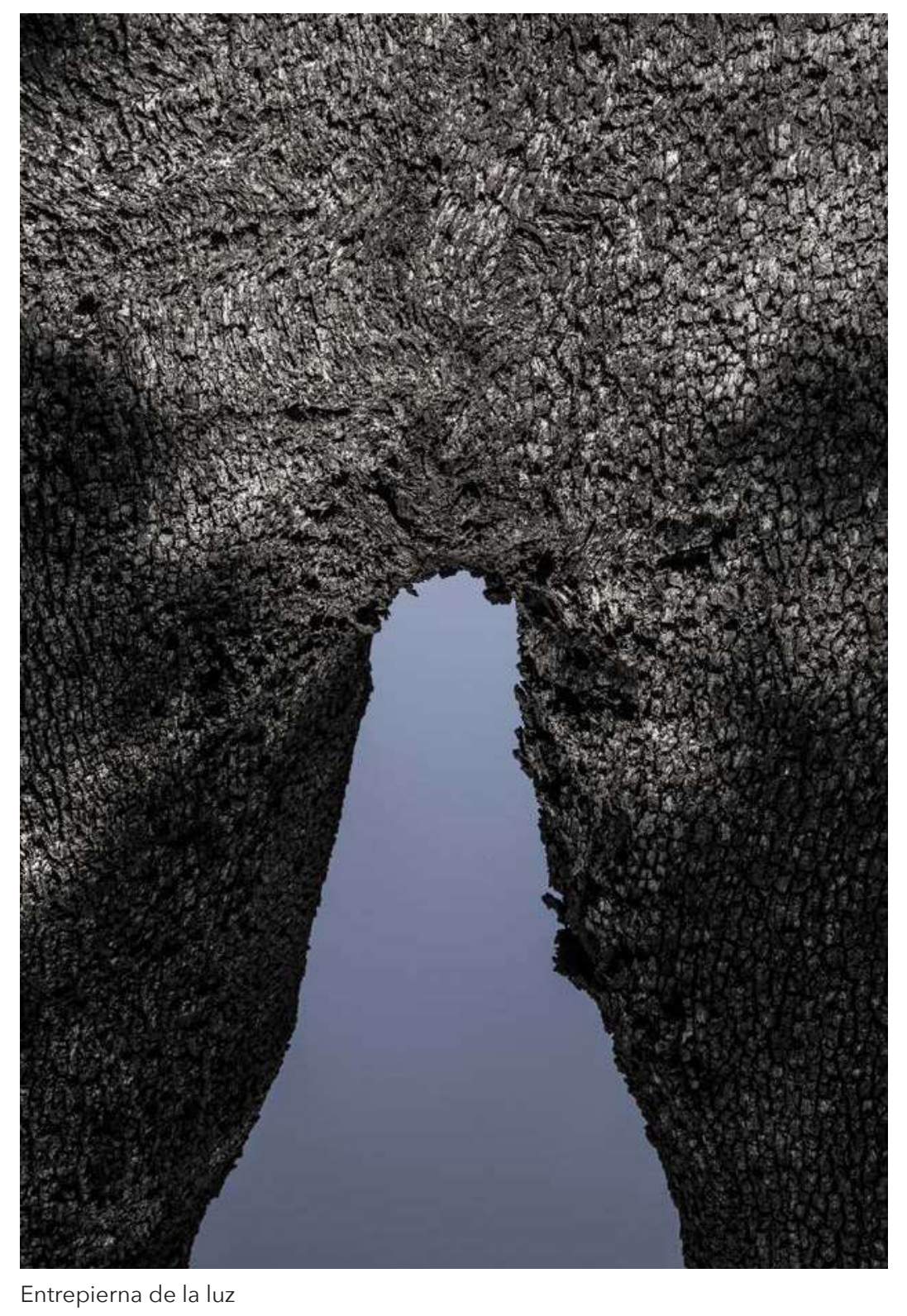

Entrepierna de la luz

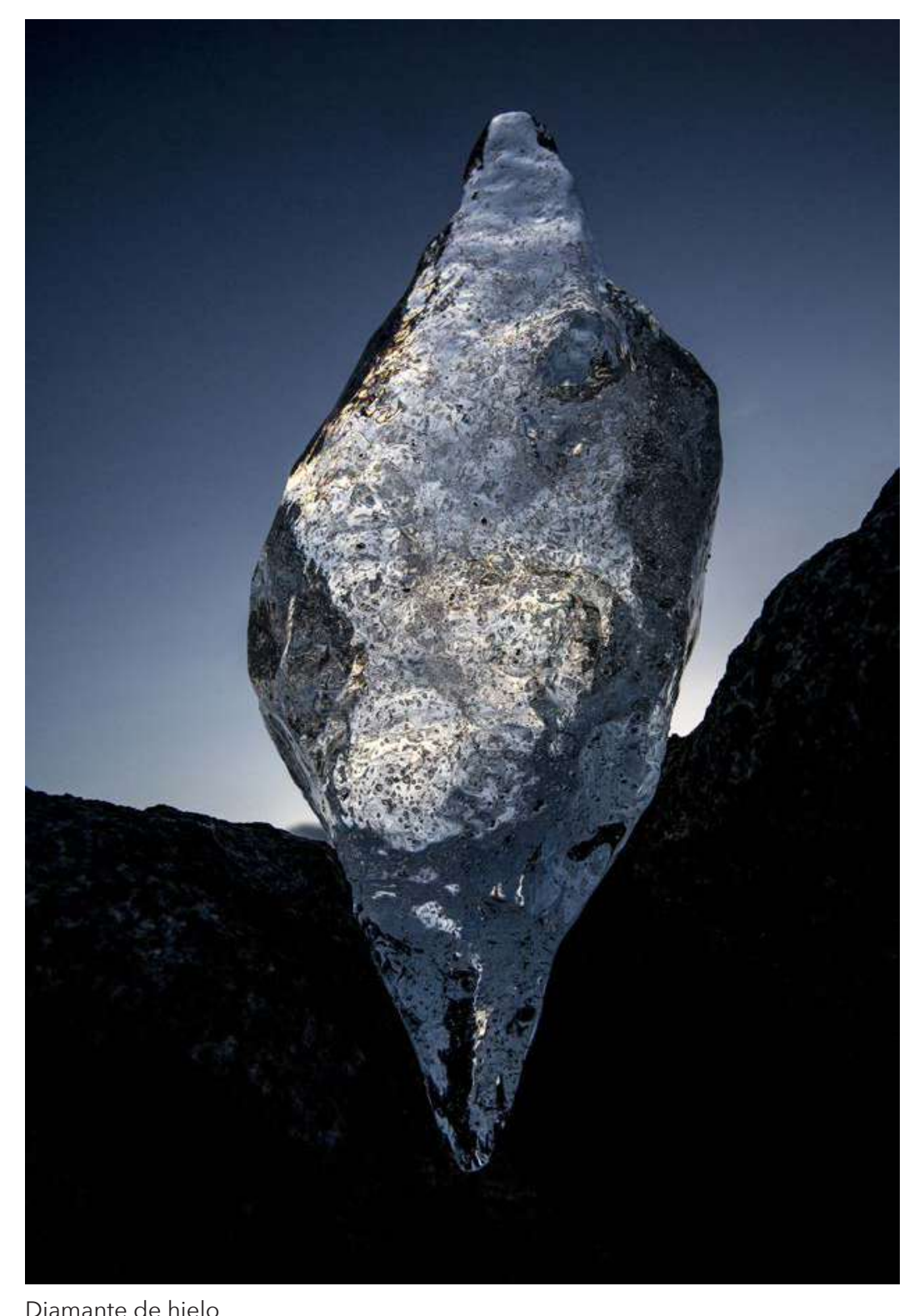

Diamante de hielo 


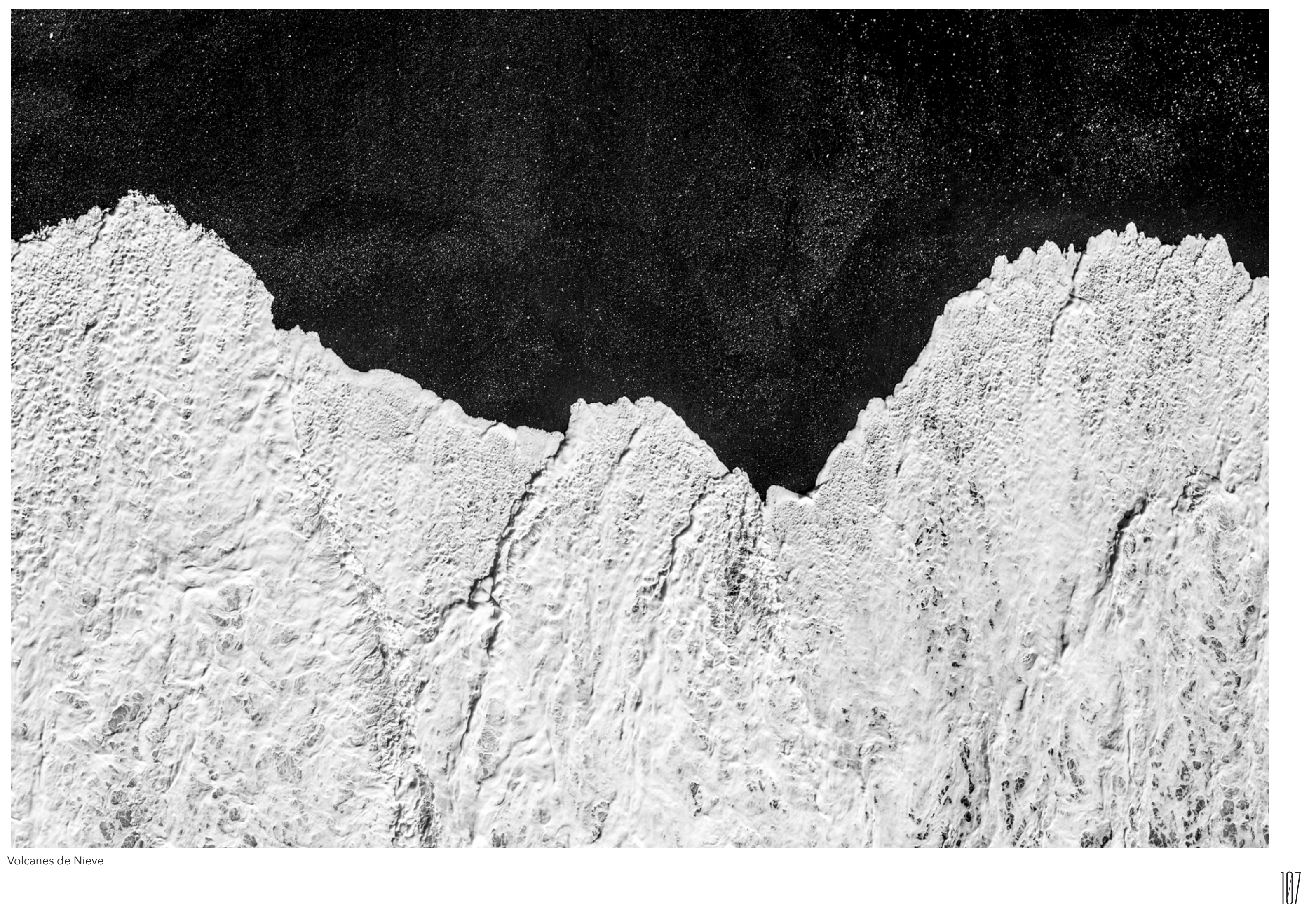

